\title{
Pandangan dunia dalam webtoon sekotengs: kajian strukturalisme genetik lucien goldmann
}

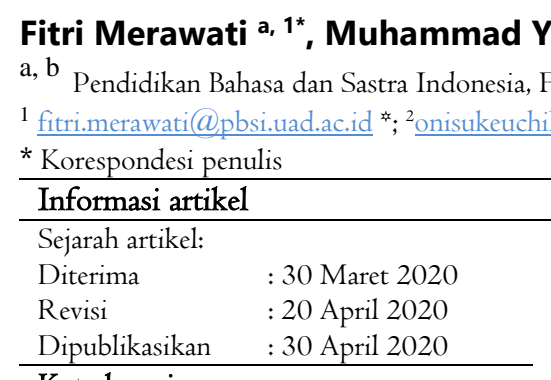

Kata kunci:

webtoon Sekotengs

fakta kemanusiaan

subjek kolektif

pandangan dunia

strukturalisme genetik

PBSTRAK dan pandangan dunia yang terdapat dalam Webtoon Sekotengs. Webtoon ini populer dengan jumlah pembaca mencapai 4,6 juta. Jenis penelitian ini adalah kualitatif yang berpusat pada deskripsi. Subjek penelitian ini adalah Webtoon Sekotengs karya Lifina, sedangkan objek penelitian ini adalah fakta kemanusiaan dan pandangan dunia pengarang. Teori yang digunakan adalah strukturalisme genetik Lucien Goldmann. Hasil penelitian ini menunjukkan bahwa dalam Webtoon Sekotengs terdapat dua jenis fakta kemanusiaan, yaitu fakta kemanusiaan kreasi kultural dan fakta kemanusiaan aktivitas sosial. Terdapat 36 data fakta kemanusiaan kreasi kultural, sedangkan data fakta kemanusiaan aktivitas sosial sebanyak 27. subjek kolektif dalam Webtoon Sekotengs didominasi oleh kelas sosial tinggi, yaitu sebanyak IO data. Tokoh utama maupun tokoh sampingan digambarkan sebagai orang kaya. Penggambaran orang miskin dapat dijumpai melalui beberapa tokoh pasien saja.Selain itu webtoon ini mempunyai pandangan dunia materialisme. Lifina melalui Webtoon Sekotengs menganggap bahwa seseorang yang dinilai tampan atau cantik dan berkelas sosial tinggi akan lebih dikagumi oleh orang lain dan menjadi idola.

\section{ABSTRACT}

Key word:

sekotengs webtoon

human fact

collective subject

world view genetic structuralism

This study aims to describe the human fact, collective subject, and world view contained in the Sekotengs webtoon. This webtoon is popular with 4.6 million readers. This type of research is qualitative, centered on description. The subject of this research is Lifina's Sekotengs webtoon, while the object of this research is the author's humanity fact and worldview. The theory used is Lucien Goldmann's genetic structuralism. The results of this study indicate that in the Sekotengs Webtoon there are two types of humanity facts, namely the fact of humanity, cultural creations and the fact of humanity social activities. There are 36 data on humanity in terms of cultural creation, while 27 in humanity data on social activities. Collective subjects in the Webtoon Sekotengs are dominated by high social class, which is as much as IO data. The main character and the side character are described as rich people. The depiction of the poor can be found through only a few patient figures. Besides this webtoon has a worldview of materialism. Lifina through Webtoon Sekotengs considers that someone who is considered handsome or beautiful and has a high social class will be more admired by others and become an idol.

\section{Pendahuluan}

Sastra merupakan media untuk mengekspresikan gagasan atau ide-ide dari seorang pengarang. Gagasan atau ide-ide ini bisa berkaitan dengan berbagai hal. Sastra dibagi menjadi sastra imjinatif dan non imajinatif. Karya imajinatif sering disebut sebagai karya fiksi. Pemahaman tentang fiksi seringa hanya diartikan sebagai sesutau yang tidak benar-benar terjadi. Tapi hal ini perli dipahami kembali tentu saja. Menurut Chimamanda Ngozie Adichie (Nnyagu: 20I4:20) fiksi merupakan perpaduan antara kenyataan
Copyright (C) 2018 Universitas Ahmad Dahlan. All Right Reserved (fact) dan imajinasi (imajination). kenyataan dalam fiksi tentu berbeda dengan kenyataan dalam non fiksi karean sudah dipengaruhi oleh adanya imajinasi. Jika dalam fiksi terdapat kenyataan artinya segala peristiwa dalam kehidupan yang sifatnya nyata dapat dijadikan sebagai bahan cerita. Salah satunya adalah tentang dunia kedokteran.

Pada era dengan teknologi yang semakin canggih, ide-ide itu tidak hanya dituangkan dalam bentuk tulisan kemudian dihadirkan melalui media cetak saja tetapi juga media lain, yaitu siber. Kehadiran sastra 
dalam dunia siber sering dijuluki sebagai sastra siber. Mawardi (2018:77) menyatakan bahwa sastra siber akrab di masyarakat posmodern karena memenuhi aspek yang menjadi ciri khas masyarakat posmodern yaitu cepat, mudah, dan dan dapat diakses secara luas. Sastra siber adalah sastra yang mencakup berbagai genre karya yang disampaikan melalui media elektronik. Salah satu yang termasuk dalam sastra siber syaitu Webtoon. Webtoon adalah komik yang didistribusikan melalui jaringan internet yang merupakan komik khas dari Korea Selatan yang dibaca dalam satu strip panjang dan berwarna.

Kim Jun Ko, selaku pencetus Line Webtoon melalui Tia Agnes (dalam Jatnik, 2018:) menyatakan bahwa Indonesia merupakan pembaca terbesar di dunia terhadap Webtoon setelah dirilis di Indonesia ada tahun 2015. Webtton menyajikan bacaan secara flelsibel sehingga dapat dikses kapan dan di mana saja melalu aplikasi Webtoon yang dapat diunduh pada ponsel pintar.

Scott McCloud mendefinisikan seni sequential dan komik sebagai gambar-gambar dan lambanglambang lain yang berdekatan, atau bersebelahan dalam urutan tertentu yang bertujuan untuk memberikan informasi atau untuk mencapai tanggapan estetis dari para pembaca. Dengan demikian, komik memanfaatkan ruang dalam media gembar untuk meletakkan gambar demi gambar sehingga membentuk alur cerita (Maharsi, 20I I: 34).

Cerita yang diangkat dalam webtoon beragam. Webtoon Sekotengs adalah salah satu judul cerita dalam Webtoon yang mengandung tema kedokteran. Sekotengs bercerita tentang kehidupan sehari-hari empat koass (ko-assisten) yang sedang praktik di rumah sakit. Cerita itu memuat istilah-istilah kesehatan, dan hal-hal yang berkaitan dengan dunia kedokteran. Tokoh-tokoh dalam Webtoon Sekotengs digambarkan dengan wajah rupawan dan tubuh proposional bagaikan artis Korea. Kesempurnaan fisik tersebut berujung pada perlakuan istimewa kepada tokoh tersebut oleh tokoh lain. $\mathrm{Hl}$ ini sekaligus menunjukkan bahwa dalam dunia kedokteran terdapat pandang dunia yang berbeda dengan profesi yang lain. Oleh karena itu perlu dikaji dengan pandangan dunia yang teori ini dikemukakan oleh Goldmann.

Webtoon ini rata-rata disukai oleh 50.000 pembaca setiap episodenya dan memiliki 4,6 juta penggemar. Oleh karena itu, dapat dikatakan bahwa Webtoon Sekotengs tergolong popular. Popular yang dimaksud ialah berdasarkan kuantitas pembaca. Selain itu, Webtoon Sekotengs dikarang oleh Lifina yang juga merupakan seorang dokter sehingga teori yang digunakan dalam lingkup struktural, khususnya stryukturalisme genetik dijadikan sebagai alat untuk menganalisis karena karya yang besar salah satu indikasinya yaitu kepopuleran sebuah karya dan perannya dalam perkembangan sastra dalam hal ini perkembangan Webtoon menjadi tolok ukur dalam kajian ini.

Kajian ini menggunakan teori strukturalisme genetik Lucien Goldmann. Meskipun diketahui bahwa ada dua tokoh yang mengembangakan Strukturalisme genetik adalah Levis Strauss (dalam lingkup strukturalisme antropologis) dan Lucian Goldman. Bahasa dan karya sastra tidak dapat lepas dari fakta sejarah yang mengondisikan kemunculan karya sastra (Dewi, 2019: 2).

Menurut Goldman, terdapat konsep yaitu fakta kemanusiaan, subjek kolektif, pandangan dunia, struktur karya sastra, dan dialektika pemahaman penjelasan (dalam Faruk, I994: I2-I6). Untuk mencapai penemuan pandangan dunia perlu melalui dua langkah yaitu mengkaji fakta kemanusiaan dan subjek kolektif.

Goldmann mengungkapkan, fakta kemanusiaan adalah segala hasil aktivitas atau perilaku manusia baik yang verbalmaupun yang fisik, yang berusaha dipahami oleh ilmu pengetahuan. Fakta itu dapat berwujud aktivitas sosial tertentu, maupun kreasi kultural seperti filsafat, seni rupa, seni musik, seni patung, dan seni sastra. Dengan kata lain, fakta-fakta itu merupakan hasil usaha manusia mencapai keseimbangan yang lebih baik dalam hubungannya dengan dunia sekitarnya (dalam Faruk, I994: I2I3).

Goldmann (dalam Nurhasanah, 2015: 139) menjabarkan pengertian pandangan dunia sebagai suatu struktur yang bersifat global dan memiliki makna. Subjek kolektif atau trans-individual merupakan konsep yang masih sangat kabur. Subjek kolektif itu dapat berupa kelompok kekerabatan, kelompok sekerja, kelompok teritorial, dan sebagainya (dalam Faruk, I994: I5).

Pandangan dunia memiliki hubangan erat dengan struktur sosial yang ada di dalam masyarakat. Pengarang yang sekaligus bagian dari masyarakat. Pengarang memiliki peran dalam karyanya untuk memberi respon terhadap lingkungan sosial dengan karakter yang sesuai dengan kelompok masyaraka. Ini kemudian disebut sebagai pandangan dunia sehingga pengarang hadir untuk mewakili kelas masyarakat tertentu (Setiawati, 2019:6).

Pengarang adalah sesoarang yang lahir di tengahtengah masyarakat dan tentu saja mengalami berbagai pengalaman berdasarkan situasi di mastyarakat tersebut. Oleh karena itu, pada penelitian sebelumnya yang dilakukan oleh Sirefina (2018: 54) mengungkapkan bahwa pandangan dunia yang dimiliki 
pengarang dipengaruhi oleh kelompok sosial tertentu tempat ia berada. Pandangan dunia merupakan produk yang dihasilkan dari hubungan antara kelompok sosial dengan situasi sosial maupun ekonomi pada situais tertentu. Produk ini juga merupakan struktur mental pengarang yang kemudian dicurahkan dalam karya sastra.

Pandangan dunia berarti memahami dunia secara total beserta dengan segala kerumitan dan keutuhannya sehingga diperoleh makna secara total. Oleh karena itu kajian ini bertujuan untuk menunjukkan fakta kemanusiaan dan subjek kolektif sehungga dapat ditemukan pandangan dunia dalam Webtoon Sekotengs.

\section{Metode}

Penelitian ini tergolong penelitian kualitatif yang memusatkan pada deskriptif. Subjek penelitian adalah Webtoon Sekotengs dan objek penelitian adalah fakta kemanusiaan dan pandangan dunia dalam webtoon tersebut. Sumber data pada penelitian ini adalah teks yang terdapat dalam Webtoon Sekotengs. Webtoon merupakan komik digital yang dapat digolongkan ke dalam dokumen atau arsip, sehingga kajian ini menggunakan metode dan teknik pengumpulan data mencatat dokumen atau arsip. Yin (dalam Sutopo, 2002: 69) menyebutnya sebagai content analysis. Peneliti bukan sekadar mencatat isi penting yang tersurat dalam dokumen atau arsip, tetapi juga tentang maknanya yang tersirat. Oleh karena itu, mengkaji beragam arsip dan dokumen sebagai sumber data harus bisa bersikap kritis dan teliti.

Instrumen penelitian dalam kajian ini menggunakan human instrument atau peneliti sebagai alat utama riset. Maksudnya adalah peneliti sebagai alat penelitian utama, meski berbagai alat pengumpulan data dimungkinkan untuk digunakan sebagai kelengkapan penunjang. Alat pengumpulan data tersebut yaitu kartu data dan tabulasi data. Kartu data untuk mengumpulkan dan memilah data, sehingga memudahkan peneliti dalam menganalsis. Tabulasi data digunakan untuk mencatat jumlah data dalam bentuk tabel yang berisi angka.

Teknik analisis data pada kajian ini menggunakan sistem kumpulan kartu dan kartu potongan informasi. Webtoon Sekotengs dibaca, setelah itu hal-hal yang penting (data) dicatat dan diorganisasikan ke dalam kategori. Pencatatan dan pengorganisasian tersebut menggunakan tabel data. Setelah data selesai dikumpulkan, selanjutnya adalah menganalisis data tersebut menggunakan teknik analisis membaca strukturalisme-genetik Lucien Goldmann.

\section{Hasil dan pembahasan}

Lynn (dalam Jang, 2017:174) menyatakan bahwa istilah webtoon merupakan kombinasi dari web dan kartun. Awal mula diciptakan webtoon adalah ketika Korea menerbitkan webcomic atau manhwa secara daring. Manhwa adalah sinonim untuk semua jenis komik di Korea yang diterbitkan baik cetak maupun online. Webtoon ini dibuat pertama kali di Korea tahun 2003 sebagai bentuk baru manhwa yang dikolaborasikan dengan teknologi digital dan jaringan situs portal web dan ponsel. Konsep format dan fungsi pembuatan webtoon dapat dilihat pada gambar berikut.

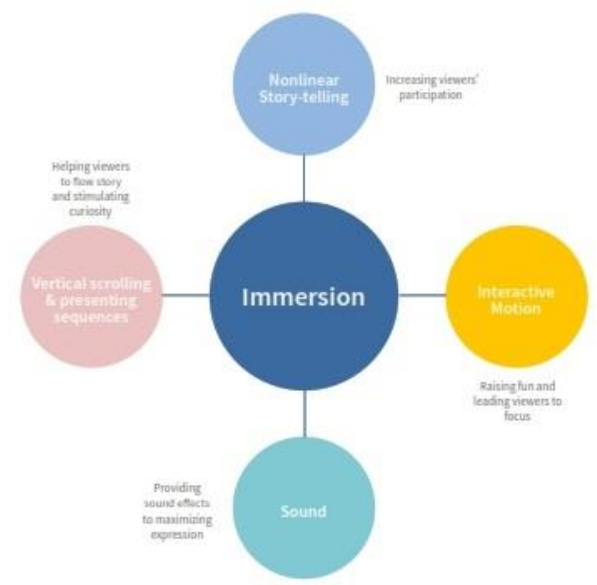

Gambar I. Gambar format dan fungsi pembuatan webtoon

Meskipun webtoon bagian dari komik tapi ada kekhasan yaitu membaca webtoon seakan menonton film dengan alur cerita. Karena itu webtoon dapat digolongkan sebagai jenis karya sastra yang berkolaborasi dengan teknologi, yaitu teknologi digital dan daring, Kelebihannya adalah karean disajikan secara daring penceritaan webtoon dapat langsung mendapat respon dari pembaca. Sehingga sastra dan masyarakat pembaca menjadi lebih dekat

Hal ini sejalan dengan Goldmannyang percaya adanya homologi antara struktur karya sastra dengan struktur masyarakat. Akan tetapi, hubungan diantara keduanya dimediasi oleh sesuatu yang disebut dengan fakta kemanusiaan dan pandangan dunia atau ideologi. Data fakta kemanusiaan dan pandangan dunia dalam Webtoon Sekotengs karya Lifina disajikan dalam tabel I dan tabel 2.

Tabel I. Data fakta kenausiaan

\begin{tabular}{lll}
\hline No. & Fakta Kemanusiaan & Frekuensi \\
\hline I. & Kreasi Kultural & \\
\hline & Moral & 9 \\
& Sopan santun & 23 \\
& Kepercayaan pengobatan & 2 \\
& tradisional
\end{tabular}


Kepercayaan pada makhluk 2

halus

Kepercayaan pada mitos 9

2. Aktivitas sosial

Pertemanan $\quad 16$

Peran keluarga $\quad$ I0

Masyarakat awam 8

Takut terhadap dunia $\quad 5$

kedokteran

Masyarakat berketuhanan

I0

Terdapat dua fakta kemanusiaan dalam Webtoon Sekotengs yang dapat ditemukan dan dianalisis. Fakta kemanusiaan tersebut meliputi fakta kemanusiaan kreasi kultural dan fakta kemanusiaan aktivitas sosial. Pada fakta kemanusiaan kreasi kultural, terdapat 9 data berupa moral, 23 data berupa sopan santun, 2 data berupa kepercayaan pengobatan tradisional, 2 data berupa kepercayaan pada makhluk halus, dan 9 data berupa kepercayaan pada mitos. Pada data fakta kemanusiaan aktivitas sosial, terdapat 16 data berupa pertemanan, I0 data berupa peran keluarga, 8 data berupa masyarakat awam, 5 data keluarga berupa takut terhadap dunia kedokteran, dan I0 data berupa masyarakat berketuhanan.

Tabel 2. Data Subjek Kolektif

\begin{tabular}{ccc}
\hline No. & Pandangan Dunia & Frekuensi \\
\hline I. & Kelas sosial tinggi & I3 \\
2. & Kelas sosial rendah & 4 \\
\hline
\end{tabular}

Terdapat dua kelas sosial dalam subjek kolektif Webtoon Sekotengs karya Lifina. Kelas sosial tersebut ialah kelas sosial tinggi dan kelas sosial rendah. Terdapat I3 data yang menunjukkan kelas sosial tinggi, sedangkan data yang menunjukkan kelas sosial rendah hanya terdapat 4.

Tabel 3. Data pandangan dunia

\begin{tabular}{llc}
\hline No. & \multicolumn{1}{c}{ Pandangan Dunia } & Frekuensi \\
\hline I. & Materialisme & 34 \\
2. & Idealisme & 25 \\
\hline
\end{tabular}

Berdasarkan data yang diperoleh dari Webtoon Sekotengs, terdapat dua pandangan dunia yang muncul. Pandangan dunia tersebut adalah idealisme dan materialisme. Namun pandangan dunia materialismelah yang mendominasi dalam Webtoon Sekotengs. Terdapat 34 data pandangan dunia materialisme, sedangkan data pandangan dunia idealisme hanya terdapat 25 .

I. Fakta kemanusiaan

\section{a. Fakta Kemanusiaan Kreasi Kultural dalam Webtoon Sekotengs Karya Lifina}

I) Moral

(I) "Kenapa kamu niruin bentuk tulisan saya... Kalau ga bisa dibaca, mending tanya aja ya, Dek...” "dr. Adrian (Lifina, 2018: episode 5).

Pada kutipan selanjutnya (I), digambarkan bahwa dokter Adrian sedang berbicara kepada salah satu mahasiswa magang. Posisi dokter Adrian tentu saja lebih senior daripada mahasiswa magang. Namun lagi-lagi Lifina menekankan betapa pentingnya moral seorang dokter melalui Webtoon Sekotengs.

Moral yang baik ditunjukkan dokter Adrian dengan meminta mahasiswa magang agar bertanya kepadanya kalau ada yang tidak diketahui. Dokter Adrian meminta bertanya dengan bahasa yang halus, tidak sambil marah, bahkan mahasiswa magang tersebut dipanggil dengan sapaan "Dek".

Dokter Adrian dapat menjadi contoh dokter yang bersikap seperti pemimpin, bukan seperti bos. Ia dapat merangkul mahasiswa magang, bukan malah menjadikannya pembantu. Moral yang baik membuat senior dan junior menjadi rekan kerja yang harmonis.

\section{2) Sopan santun}

(2) "Maaf ya pak, saya tekan perutnya... kalau sakit bilang ya pak. Kalau saya ketok punggungnya seperti ini, terasa sakit pak?" "Dien (Lifina, 2018: episode 8).

Kata maaf tidak selalu diucapkan karena seseorang merasa bersalah. Dien, seorang mahasiswa magang sedang meminta maaf kepada pasien sebelum memeriksa. Hal itu ia lakukan karena tubuh pasien sepenuhnya adalah hak dan milik pasien. Tenaga medis tetap harus meminta ijin terlebih dahulu kepada pasien sebelum melakukan pemeriksaan sebagai bentuk sopan santun.

Kutipan (2) tersebut juga menjelaskan bahwa betapa pentingnya sopan santun dalam menangani pasien. Kata maaf sebelum memeriksa dibudayakan oleh tenaga medis supaya pasien merasa nyaman dan mempunyai kedekatan emosi. Hal itu membuat pasien lebih mudah untuk sembuh karena telah percaya kepada dokter. Selain itu, tubuh dan pikiran pasien pun akan ikut santai.

\section{3) Kepercayaan pengobatan tradisional}

(3) "Iya dok. Habis jatuh dari motor seminggu yang lalu. Saya ga tau dia bawa motor. Sudah saya bawa ke dukun urut, tapi katanya gapapa. Bengkaknya gara-gara racunnya keluar. Tapi kok malah makin bengkak dan sakit." "Ibu pasien (Lifina, 2018: episode 3).

Kutipan (3) menunjukkan bahwa ada seorang anak yang dibawa ke dukun oleh ibunya dikarenakan ia terjatuh dari sepeda motor. Hal tersebut membuktikan bahwa ibu percaya kepada pengobatan tradisional atau dukun. Ia segera membawa anaknya ke dukun ketika ia tahu bahwa anaknya sakit. Ibu juga percaya kepada dukun bahwa bengkak yang diderita anaknya 
dikarenakan racunnya keluar, padahal anak tersebut sakit karena terjatuh dari sepeda motor sehingga tidak ada kaitannya dengan racun. Pengobatan medis menjadi pilihan kedua bagi ibu. Hal tersebut terbukti dari tindakan ibu yang baru membawa anaknya ke rumah sakit setelah bengkaknya semakin besar dan semakin sakit.

\section{4) Kepercayaan pada makhluk halus}

(4) "Jangan sampai kamu pingsan karena ketakutan melihat hantu. Rrr ra rarak rakaaa barusan a ada yang lewat!!! Beneran kok!!! Masa kamu gak lihat? ?" "Ezra (Lifina, 2018: episode 7).

Kebudayaan Indonesia memang sangat kental dengan dunia ghaib. Tidak jarang masyarakat juga percaya dengan keberadaan makhluk gaib tersebut. Agama yang dianut di Indonesia juga mengakui keberadaan makhluk ghaib, sehingga keberadaan makhluk ghaib memang sangat berdampingan dengan kehidupan manusia.

Pada kutipan tersebut diceritakan bahwa salah satu mahasiswa magang melihat hantu ketika sedang berjalan di koridor. Sudah pasti mahasiswa magang adalah calon dokter, seorang yang berpendidikan, terlebih dibidang sains. Namun semua itu tidak membuatnya jauh dari kebudayaan Indonesia yang sangat kental dengan makhluk halus. Ia tetap percaya dengan keberadaan makhluk halus.

Kepercayaannya terhadap makhluk halus bahkan sampai membuatnya ketakutan. Hal itu dapat dibuktikan dengan mendadak ia menjadi gagu ketika melihat hantu. Ketidaklancaran berbicara secara mendadak karena suatu hal adalah bukti bahwa seseorang tersebut sedang merasa takut.

\section{5) Kepercayaan pada mitos}
(5) "Bener dok! Kalo tiap malem IGD sepi gini hidup kita damai sentosa!
eh?! Aku keceplosan! ${ }^{*}$ Mas Baim
Baim... kamu ngomong apa barusan hah?!
"Mbak Asri
Berani beraninya bocah ini... ${ }^{*} d r$. Erina
Dokter! Kami warga rt 99 keracunan es duren basi! "Warga
Masih ada dua bus lagi menyusul! Semuanya muntaber!" Warga (Lifina, 2018: episode 2O).

Salah satu mitos yang mereka yakini adalah larangan mengucapkan "IGD sepi". Mas Baim yang terlalu senang karena berjaga dengan Raka dan Dien, lupa dan tidak sengaja mengucapkan "IGD sepi". Reaksi dari Mas Baim selanjutnya adalah mengucapkan "eh, keceplosan" dengan penuh sesal. Reaksi tersebut menunjukkan bahwa Mas Baim sangat percaya dengan mitos itu. Apabila Mas Baim tidak percaya, maka ia tidak akan merasa bersalah, merasa biasa saja, dan tidak mempunyai beban terkait apa yang baru saja ia ucapkan.

Reaksi dari Mbak Asri juga menunjukkan bahwa ia sangat percaya dengan mitos itu. Ia mengatakan "Baim... kamu ngomong apa barusan hah?!" yang artinya tidak percaya dengan apa yang baru saja dikatakan oleh Mas Baim. dr. Erina pun demikian, ia sangat takut dengan resiko ucapan Mas Baim. Ia mengucapkan "Berani beraninya bocah ini..." yang artinya adalah ingin mengancam Mas Baim karena baru saja mengatakan sesuatu yang berakibat buruk. Mbak Asri dan dr. Erina menunjukkan ketakutannya dengan reaksi ucapannya. Hal itu tidak perlu diucapkan apabila mereka tidak percaya dengan mitos itu.

Kutipan itu berakhir dengan munculnya warga yang mengalami keracunan makanan. Jumlahnya pun sangat banyak, yaitu dua bus. Kejadian itu menggambarkan betapa dipercayanya mitos tersebut di lingkungan rumah sakit. Pasien yang banyak tidak membuat Mbak Asri dan dr. Erina menyalahkan Raka dan Dien, namun tetap menyalahkan Mas Baim karena ucapannya.

\section{b. Fakta Kemanusiaan Aktivitas Sosial dalam} Webtoon Sekotengs Karya Lifina

\section{I) Pertemanan}

(6) "Kalau kamu mau nonton kembang api dengan keluargamu, biar aku saja yang jaga malam tahun baru." "Raka (Lifina, 2018: episode 44).

Pertemanan dalam Webtoon Sekotengs sangatlah terasa. Kutipan (6) menceritakan Raka dengan ikhlas bersedia jaga malam menggantikan temannya yang ingin melihat kembang api pada malam tahun baru.

Tahun baru adalah saat yang dinantikan banyak orang, terutama anak muda. Mereka ingin menghabiskan waktu bersama orang terdekat sambil menikmati pesta kembang api. Tidak jarang para pekerja yang bekerja secara bergiliran menginginkan masuk pagi atau libur supaya pada malam harinya bisa menikmati malam tahun baru. Namun karena banyak yang menginginkannya, perebutan giliran jaga dapat menimbulkan pertengkaran.

Raka yang tidak mendapat giliran jaga malam, dengan ikhlas menawarkan pertukaran jaga supaya temannya dapat melihat kembang api. Hal itu tidak akan ia lakukan kalau Raka tidak mempunyai ikatan pertemanan yang kuat. Ikatan pertemanan yang kuat dapat membuat ego menjadi turun dan lebih mementingkan temannya.

2) Peran Keluarga

(7) "Ya, sebenranya mau atau engga itu kan dari gian sendiri... 
Kalau kamu ga mau olahraga juga ibu ga bisa maksa...

Tapi menurut ibu sih, tujuan utama dari diet dan olahraga itu bukan sekedar penampilan saja.

Tapi lebih ke menjaga kesehatan, apalagi kamu punya riwayat penyakit.

Ibu khawatir kalau kamu tidak menurunkan berat badan, nantinya kamu akan jatuh sakit lagi." "Ibu Ezra (Lifina, 2018: episode 48).

Ezra adalah seorang mahasiswa yang berarti usianya sudah mulai dewasa. Namun Ezra tetaplah seorang anak dari ibunya. Ia selalu diperhatikan oleh ibunya. Bukan berarti Ezra adalah anak yang manja, namun ibu bertindak demikian karena peduli dengan Ezra. Kepedulian itulah yang mencerminkan peran keluarga.

Seorang ibu tidak akan mungkin menasihati orang lain. Hal itu dikarenakan orang lain bukanlah menjadi tanggung jawabnya. Seorang ibu akan sangat sedih apabila anaknya jatuh sakit. Oleh karena itu ibu pasti melakukan yang terbaik bagi anaknya, termasuk menasihati kesehatan anaknya.

\section{3) Masyarakat awam}

(8) "Iya payah deh, dokter kok sakit, gimana bisa nolong pasien. ${ }^{*}$ Pasien

Jadi dokter kok gak bisa jaga diri." "Pasien lain (Lifina, 2018: episode 26).

Masyarakat awam ditunjukkan melalui tokoh pasien dalam kutipan (8). Pasien tersebut beranggapan bahwa dokter adalah orang yang pandai mengobati. Oleh karena itu seorang dokter akan terlihat payah kalau sampai sakit. Seorang dokter haruslah selalu dalam keadaan sehat.

Padahal kenyataannya tidak seperti itu. Seorang dokter setiap hari berinteraksi dengan orang sakit. Penyakit yang dideritaa pasien juga bermacammacam. Oleh sebab itu seorang dokter lebih rentan mengidap suatu penyakit. Dokter hanyalah manusia biasa yang memiliki pengetahuan lebih tentang dunia medis, sehingga dokter dapat menyembuhkan pasien. Pengetahuan dasar seperti itu tidaklah dipahami oleh pasien dalam kutipan (8). Oleh karena itu ia termasuk ke dalam masyarakat awam.

\section{4) Takut terhadap dunia kedokteran}

(9) "Kakak pernah dioperasi tidak? Apa rasanya sakit?" "Alya (Lifina, 2018: episode 32).

Perasaan takut memang sering kali dirasakan oleh pasien, apalagi pasien yang hendak dioperasi. Ketakutan tersebut dapat berwujud kecemasan. Kutipan dalam episode tersebut menceritakan bahwa Alya adalah pasien perempuan usia SD yang hendak dioperasi. Alya digambarkan mengalami ketakutan menjelang operasi. Ketakutannya diekspresikan dengan bertanya kepada "kakak" tentang sakit tidaknya waktu dioperasi. Kakak yang dimaksud oleh Alya adalah mahasiswa magang, yaitu Ezra.

Alya mempunyai kedekatan dengan Ezra. Kedekatan tersebut berasal dari usaha Ezra untuk membantu menghilangkan atau mengurangi ketakutan Alya. Hampir setiap kali diperiksa oleh dokter ataupun mahasiswa magang, Alya selalu menolak karena takut. Puncak ketakutan Alya adalah kutipan (9). Ia sangat cemas dengan apa yang akan ia rasakan ketika dioperasi. Apabila Alya tidak mengalami ketakutan, ia tidak akan cemas menghadapi operasi dan akan merasa tenang.

\section{5) Masyarakat berketuhanan}

(I0) "Karena kita ini hanya manusia tidak punya kuasa apapun terhadap nyawa manusia lain. Sepintar apapun, seahli apapun, kita hanya bisa berusaha sebaik mungkin. Hasilnya tetap tergantung pada sang pencipta." "dr. Ananda, Sp BTKV (Lifina, 2018: episode 33).

Wujud masyarakat berketuhanan terlihat dari sosok dr. Ananda. Ia diceritakan sebagai dokter ahli bedah jantung. Kepintarannya dalam bidangnya sudah tidak diragukan lagi. Namun ia tetap berpendapat bahwa ia hanyalah manusia biasa. Segala sesuatu bergantung kepada sang pencipta, dokter hanya bisa berusaha sebaik mungkin. Anggapan seperti itu hanya terjadi ketika seseorang tunduk akan kuasa Tuhan. Seseorang yang tidak mengakui kekuasaan Tuhan pasti beranggapan bahwa kesembuhan berasal dari usaha dokter dan keberuntungan.

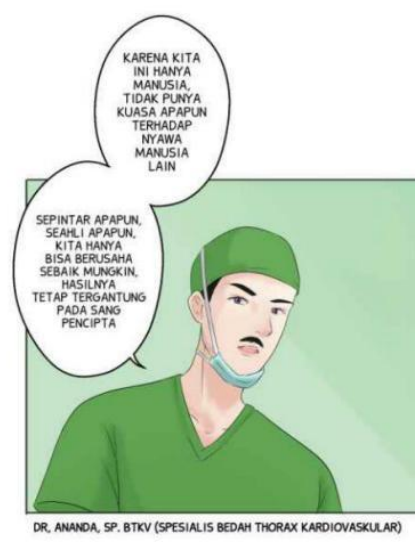

Gambar I. Gambar Webtoon Sekotengs episode 33 2. Subjek Kolektif

\section{Subjek Kolektif dalam Webtoon Sekotengs Karya Lifina}

Subjek kolektif adalah sekelompok individu yang berbagi budaya, tujuan, gaya hidup, dan pandangan hidup yang sama. Dengan kata lain, subjek kolektif adalah trans-individu dengan fakta kemanusiaan. Faruk juga menambahkan bahwa subjek 
kolektif dapat dibentuk dalam kelompok keluarga, rekan kerja, dan kelompok teritorial. Berdasarkan penjelasan ini, subjek kolektif pada dasarnya adalah makhluk sosial yang hidup di bawah aturan, norma, atau kebiasaan yang sama (Wijianto, 2020: 53). Subjek kolektif yang terdapat dalam Webtoon Sekotengs yaitu sebagai berikut.

\section{I) Kelas sosial tinggi}

(I) "Karena sebagai "darah biru", lo bisa berlaku seenaknya. Mau jadi dokter spesialis nanti juga tinggal minta sama ortu lo kan?" ${ }^{*}$ Dean (Lifina, 2018: episode 53).

Pada kutipan (I), Dean sedang mengajak bicara kepada sesama mahasiswa magang, yaitu Vino. Dean beranggapan bahwa Vino adalah seorang "darah biru". Bukan berarti keturunan raja, namun "darah biru” yang dimaksud adalah darah biru dalam lingkungan kedokteran. Ayah dan kakak Vino adalah seorang dokter spesialis. Posisi dokter spesialis tentu lebih mapan dan secara pengetahuan lebih pandai daripada dokter umum. Kekayaan dan posisi kerja yang tinggi adalah salah satu bentuk kelas sosial tinggi. Pendapatan dokter spesialis lebih banyak daripada dokter umum, selain itu dokter spesialis juga dipandang lebih tinggi daripada doker umum. Oleh sebab itu kutipan tersebut menunjukkan bahwa kelas sosialnya adalah kelas sosial tinggi.

Dean juga mengatakan bahwa Vino bisa saja menjadi dokter spesialis asalkan minta kepada orang tuanya. Permintaan menjadi dokter spesialis bukan berarti langsung bisa terkabulkan, namun setidaknya proses untuk menjadi dokter spesialis lebih dimudahkan. Vino tidak akan sulit untuk membayar kuliah dokter spesialis, ia juga bisa bertanya banyak kepada keluarga. Hal itu akan dirasa sulit bagi orang biasa yang akan kuliah dokter spesialis. Kemudahankemudahan yang Vino dapatkan dikarenakan ia termasuk ke dalam kelas sosial tinggi.

\section{(2) "Rumah sakit internasional.}

Nah, bagaimana perasaanmu, Ezra?" "dr. Ananda H., Sp. BTKV (K) (Lifina, 2018: episode 8I).

Kutipan selanjutnya menunjukkan percakapaan antara dokter dengan Ezra. Ezra adalah seorang mahasiswa magang yang mengidap disfungsi jantung. Ia hendak dioperasi demi kesembuhannya. Rumah sakit tempat ia akan dioperasi diceritakan di sebuah rumah sakit internasional. Penegasan jenis rumah sakit ini bukan terjadi karena kebetulan saja. Pengarang dengan sengaja membuat latar tempat operasi Ezra di rumah sakit internasional. Hal ini untuk menunjukkan bahwa Ezra adalah termasuk dalam kelas sosial tinggi.
Rumah sakit internasional mampu menampung pasien dari negara lain yang tidak bisa dirawat di negara tersebut. Kemampuannya menampung menunjukkan bahwa rumah sakit internasional lebih modern, lebih lengkap dari sisi alat medis, dan dokternya juga lebih kompeten. Disisi lain, biaya untuk menjalani perawaatan di rumah sakit internasional juga lebih mahal daripada rumah sakit yang lain. Sejalan dengan itu, pengarang telah menunjukkan bahwa Ezra berasal dari kalangan berada, atau kelas sosial tinggi. Pengarang bisa saja membuat latar tempat operasi disebuah rumah sakit umum daerah (RSUD) atau di rumah sakit umum provinsi (RSUP). Namun hal itu tidak ia lakukan karena akan terkesan berkelas sosial rendah.

\section{(3) "Ayahmu semalam menelpon saya, katanya "Raka sangat khawatir dengan keadaan temannya”. Beliau minta agar tim rumah sakit melakukan yang terbaik. Tapi beliau bilang tidak bisa langsung kesini karena sedang ada urusan di Jerman. Sebagai owner rumah sakit, ayahmu pasti sangat sibuk ya..." * dr. Ananda H., Sp. BTKV (K) (Lifina, 2018: episode 82).}
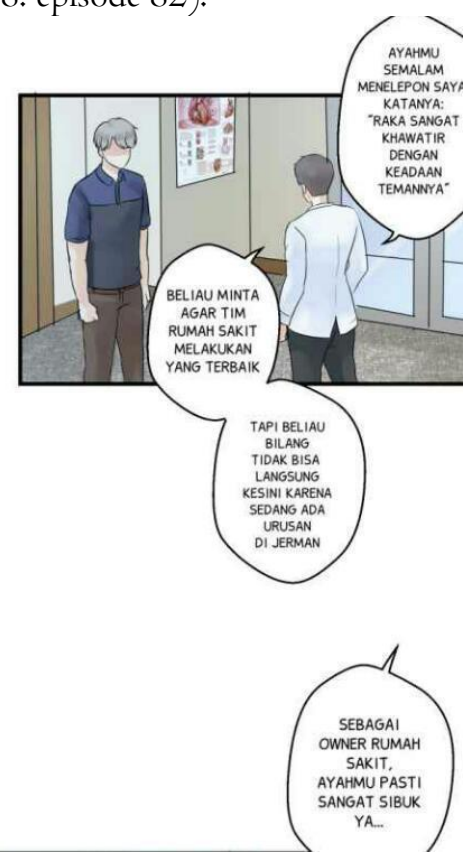

Gambar 2. Gambar Webtoon Sekotengs episode 82

Percakapan tersebut terjadi antara dr. Ananda dengan Raka. dr. Ananda adalah dokter yang akan mengoperasi Ezra, sedangkan Raka adalah teman mahasiswa magang Ezra. Mereka berbincang sebelum Ezra dioperasi.

dr. Ananda menyebut ayah Raka dengan sapaan "beliau”. Kelas sosial tinggi dari ayah Raka mulai terlihat dari sapaan itu. dr. Ananda adalah dokter spesialis bedah jantung, dengan kata lain ia dipandang tinggi di lingkungan rumah sakit. Namun ia masih menghormati ayah Raka dengan menyebutnya 
"beliau". Hal ini menunjukkan bahwa posisi ayah Raka lebih tinggi dari dr. Ananda.

Bukti kelas sosial tinggi yang lain adalah ketika ayah Raka menelpon dr. Ananda untuk melakukan yang terbaik. Permintaan tersebut lebih terkesan permintaan bos kepada pegawainya, bukan permintaan kelas sosial rendah kepada dokter. Tidak mungkin kelas sosial rendah menelpon dokter hanya dikarenakan anaknya khawatir kepada seseorang yang akan dioperasi dokter tersebut.

Bukti selanjutnya adalah ketika dr. Ananda mengatakan bahwa ayah Raka sedang ada urusan di Jerman sehingga tidak bisa datang. Urusan di luar negeri, terlebih di negara maju seperti Jerman membuat kelas sosial ayah Raka terlihat tinggi. Ditambah lagi, dr. Ananda mengatakan bahwa ayah Raka adalah pemilik rumah sakit. Sudah bisa dipastikan bahwa ayah Raka termasuk kelas sosial tinggi.

(4) "Dokter Raka idaman banget ya. Udah spesialis btkv, masih muda, ganteng, sering sharing ilmu, murah senyum lagi. "salah seorang koass baru I

Dia kan cucunya pendiri danaiswara hospital group, mungkin ga boleh sembarangan pilih pasangan." "salah seorang koass baru 2 (Lifina, 2018: episode epilog).

Kutipan (4) terjadi beberapa tahun kemudian. Raka sudah menjadi dokter spesialis jantung. Waktu itu ia sedang mengoperasi pasien. Percakapan terjadi diantara mahasiswa magang yang membatu Raka mengoperasi.

Kelas sosial tinggi terlihat ketika salah satu mahasiswa magang mengatakan "udah spesialis btkv". Di lingkungan rumah sakit, dokter spesialis adalah posisi yang terpandang. Oleh sebab itu Raka termasuk kelas sosial tinggi. Selain itu, mahasiswa magang yang lain mengatakan bahwa Raka adalah "cucunya pendiri danaiswara group”. Kalimat tersebut mengungkapkan bahwa Raka berasal dari kalangan kelas sosial tinggi.

\section{2) Kelas Sosial Rendah}

(5) "Iya dok. Habis jatuh dari motor seminggu yang lalu. Saya ga tau dia bawa motor. Sudah saya bawa ke dukun urut, tapi katanya gapapa. Bengkaknya gara-gara racunnya keluar. Tapi kok malah makin bengkak dan sakit." "Ibu dari pasien anakanak (Lifina, 2018: episode 3).

Kutipan (5) tentang seorang ibu pasien yang sedang menceritakan masalah anaknya. Ia percaya dengan perkataan dukun bahwa bengkak yang diderita anaknya dikarenakan racunnya keluar. Padahal ia tahu kalau bengkak yang dialami oleh anaknya dikarenakan terjatuh dari sepeda motor. Ketidaktahuannya tentang sumber penyakit sederhana menunjukkan bahwa ibu termasuk kelas sosial rendah.

(6) "Soalnya kalo yang saya tonton disinetron pas peran antagonisnya matiin infuse, protagonisnya langsung sekarat dok." "Ibu pasien (Lifina, 2018: episode 6).

Selanjutnya adalah kutipan tentang ibu pasien yang lain. Ia sangat percaya dengan adegan yang ada disinetron. Kepercayaannya pada adegan sinetron merupakan salah satu tanda bahwa ia mudah terpengaruh. Kelas sosial rendah pada umumnya adalah orang yang kurang berpendidikan sehingga mereka mudah terpengaruh. Oleh karena itu kutipan tersebut menunjukkan kelas sosial rendah.

\section{Pandangan dunia}

Eggy Fajar Andalas (dalam Safitri, 2019:25) mengemukanan bahwa pandangan dunia yang beragam neunjukkan bahwa sesuangguhnya karya sastra tidak hanya memiliki satu fungsi estetika saja tetapi juga memiliki pesan ideologis sebagai tanggung jawab moral dari karya tersebut.

Dalam pandangan Goldmann (Nazemian. 2019:255) ideologi berusaha menemukan solusi untuk masalah-masalah yang menimpa kelas sosial; pada kenyataannya, ideologi adalah garis masalah dan solusi sosial yang berkelanjutan. Ideologi ini bukan produk subjek tetapi produk masyarakat; itu memanifestasikan dirinya dalam karya-karya sastra, intelektual, dan artistik dari satu kelas. Oleh karena itu, karya-karya sastra memiliki aspek sosial dan individual, karena mereka mewakili kesadaran kelompok atau kelas yang menjadi milik penulis buku.

Pandangan dunia yang muncul dalam Webtoon Sekotengs adalah materialisme dan idealisme

\section{I) Materialisme}

Berdasarkan Kamus Besar Bahasa Indonesia, materialisme adalah suatu paham yang mengedepankan materi sebagai tolok ukur kebahagiaan dan pencapaian. Materi, harta atau kekayaan menjadi dasar seseoarang dianggap mulia atau tidak sehingga berpengaruh pada tingkatan seseorang untuk dihargai atau dihormati (Iskandar: 2012: 27).

Kutipan dalam teks webtoon yang menunjukkan adanya pandangan dunia materialisme antara lain sebagai berikut.

\section{Pasien ibu muda I: "Wah!"}

Pasien ibu muda 2: "Ada dr. Raka!

Pasien ibu muda I: "Kyaa ganteng banget ya!

Pasien ibu muda 2: "Lumayan cuci mata jeung!" (Lifina, 2018: episode II).

Wujud fisik seseorang mengacu pada materi. Wajah tampan, cantik, atau jelek adalah penilaian yang didasarkan pada bentuk fisik seseorang, teks webtoon tersebut merupakan contoh penilaian berdasarkan fisik seseorang. Kutipan teks webtoon bercerita tentang dua 
orang pasien ibu muda sedang mengagumi ketampanan salah satu koass bernama Raka. Kata "wah!" menunjukkan ketertarikannya saat melihat Raka. Pasien tersebut takjub dan mengagumi ketampanan Raka. Kalimat selanjutnya adalah "Ada dr. Raka!" yang diucapkan oleh pasien yang kedua. Ia juga terkejut dan senang karena bisa melihat ketampanan Raka. Pasien I melanjutkan perbincangan dengan mengatakan "kyaa ganteng banget ya!". Hal itu menunjukkan kekagumannya pada wajah Raka. Pasien 2 mengatakan "lumayan cuci mata jeung". Cuci mata seharusnya dilakukan dengan air atau sesuatu yang menyegarkan. Selain itu, dari aktivitas cuci mata membuat wajah yang layu menjadi segar kembali. Berdasarkan penjelasan tersebut, Raka merupakan sosok yang dianggap ketampanannya mampu membuat pasien menjadi segar kembali.

Raka: "Maaf, coba nona tenang dulu, jelaskan pelan-pelan kejadiannya. Setelah itu boleh saya periksa?

Pasien perempuan muda: "Silakan periksa dok. Aku ikhlas jiwa dan raga.

Raka: "Lho pasiennya tiba-tiba mimisan!" (Lifina, 2018: episode 17).

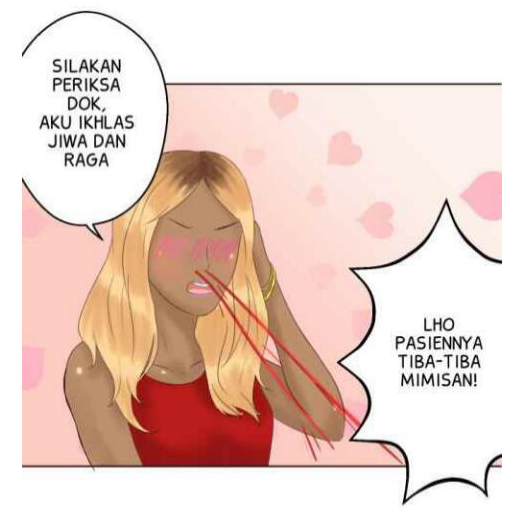

SETELAH ITU RAKA DILARANG SENYUM LAGI

FNDUS:

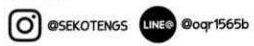

Gambar 3. Gambar Webtoon Sekotengs episode 17

Seorang pasien perempuan muda mengatakan bahwa ia telah mengikhlaskan jiwa dan raganya kepada Raka. Mengikhlaskan jiwa dan raga artinya menyerahkan seluruh hidupnya. Padahal hubungan antara pasien perempuan muda dengan Raka hanya sebatas hubungan pasien dengan dokter. Kejadian itu terjadi ketika Raka sedang memeriksa pasien. Peristiwa itu bisa terjadi karena ketampanan Raka yang digambarkan luar biasa, sehingga seseorang yang belum kenal pun mau menyerahkan jiwa dan raga.

Peristiwa selanjutnya adalah mimisan yang dialami oleh pasien perempuan muda. Mimisan biasanya terjadi karena benturan benda tumpul yang mengenai hidung. Benturan tersebut melukai bagian dalam hidung dan akibatnya adalah berdarah. Sebab lain dari mimisan adalah bersin yang terlalu kuat sehingga dinding dalam hidung mengalami luka dan berdarah. Namun pasien perempuan muda tidak mengalami hal itu. Ia tiba-tiba mengalami mimisan setelah melihat ketampanan Raka.

Komik-komik atau film animasi Jepang sering kali menceritakan perempuan atau laki-laki yang mendadak mimisan saat melihat lawan jenisnya yang sangat cantik atau tampan. Alasan itulah yang membuat pasien perempuan muda mimisan secara mendadak setelah melihat ketampanan Raka. Reaksi tubuhnya menyatakan bahwa ia menganggap Raka adalah sosok yang sangat tampan.

Terra: "Jadi aku harus minum obat apa kak supaya cepet sembuh?" "\#*

Ezra: "Istirahat sama minum vitamin aja biar cepet sembuh! Kalo sakit banget baru minum paracetamol."

Terra" "Bener kak cukup pake vitamin C aja aku udah sembuh. Cogan!"

(Lifina, 2018: episode 24).

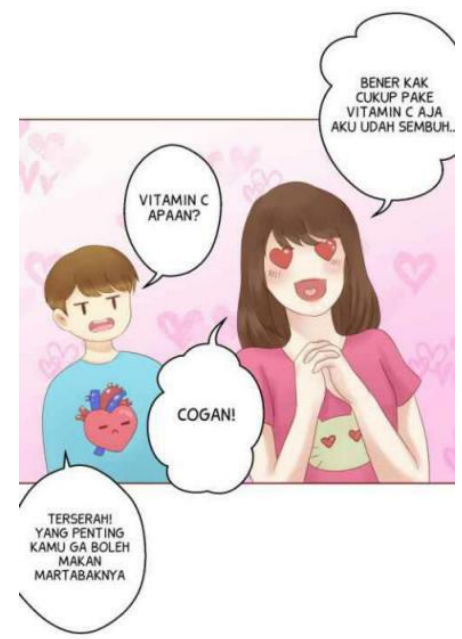

Gambar 4. Gambar Webtoon Sekotengs episode 24

Percakapan pada kutipan tersebut terjadi di rumah Ezra, salah satu mahasiswa magang. Terra, adik Ezra sedang mengalami sakit pada bagian tenggorokan. Ia diminta oleh Ezra untuk minum vitamin $C$ supaya cepat sembuh. Tiba-tiba Raka datang ke rumah Ezra. Seketika Terra sembuh sambil mengulangi perkataan Ezra bahwa ia hanya perlu vitamin $\mathrm{C}$ saja.

Vitamin C biasanya bersumber dari buahbuahan segar. Setelah memakan buah-buahan segar, tubuh juga menjadi segar. Namun vitamin C yang Terra maksud adalah Raka. Terra sangat mengagumi ketampanan Raka, sehingga penyakitnya sembuh ketika melihat ketampanan Raka. Terra juga menganggap bahwa ketampanan Raka sangat menyegarkan. Selain itu, secara spontan Terra 
mengatakan "cogan!" ketika melihat Raka. Cogan adalah akronim dari cowok ganteng. Terra benarbenar mengakui secara lisan tentang ketampanan Raka. 2) Idealisme

Pandangan dunia yang disajikan pengarang selain materialisme adalah idealisme.

Ezra: "Kalo ngomong sama pasien jangan terlalu gloomy dong. Harus lebih ceria! Aku perhatiin kamu juga jarang banget senyum ke pasien." (Lifina, 2018: episode I8).

Ezra sedang memberi tahu teman magangnya supaya lebih bersikap ramah kepada pasien. Ia menyarankan untuk selalu senyum kepada pasien. Ramah dan senyum merupakan bagian dari pelayanan. Pasien akan merasa nyaman dan senang apabila tenaga medis ramah dan murah senyum. Kutipan tersebut memberitahukan kepada pembaca bahwa ada suatu sikap yang harus diutamakan ketika melayani pasien. Ramah dan murah senyum membuat pasien menjadi nyaman merupakan konsep sebuah ide. Raka: "Kamu tahu soal "informed consent" kan? Mau lisan atau tulisan, sebelum memeriksa, kita wajib meminta izin. Tubuh pasien adalah sepenuhnya hak otonomi mereka, kita tidak bisa memaksakan tindakan atau pemeriksaan apapun." (Lifina, 2018: episode 60).

Idealisme selanjutnya ditunjukkan dalam kutipan tersebut yang menunjukkan bahwa Raka sedang menasihati mahasiswa magang baru yang belum begitu paham. Mahasiswa magang baru itu baru saja memeriksa tubuh orang lain dengan tidak meminta ijin terlebih dahulu. Tubuh pasien adalah sepenuhnya milik pasien, jadi dokter tidak berhak memeriksa kalau belum meminta ijin.

Tubuh pasien sepenuhnya milik pasien adalah sebuah gagasan, konsep, atau ide. Meminta ijin kepada pasien sebelum memeriksa juga sebuah ide. Dokter harus berpegang teguh pada ide tersebut. Oleh karena itu kutipan tersebut termasuk kedalam pandangan dunia idealisme.

\section{Simpulan}

Unsur-unsur budaya Indonesia menjadi latar belakang dalam setiap episode Webtoon Sekotengs. Selain itu, hubungan manusia dengan manusia lain serta hubungan manusia dengan Tuhan diceritakan oleh Lifina dalam Webtoon Sekotengs. Fakta kemanusiaan kreasi kultural menunjukkan bahwa tokoh yang dihadirkan masih menunjukkan identitasnya sebagai warga negara Indonesia yang kaya akan budaya. Melalui aktivitas sosial, dapat disimpulkan bahwa tokoh yang dihadirkan sangat baik antar sesama manusia, dan juga merupakan manusia yang berketuhanan.
Subjek kolektif yang mendominasi dalam Webtoon Sekotengs adalah kelas sosial tinggi. Tokohtokoh utama digambarkan sebagai orang kaya. Tokoh pendukung juga didominasi dari kalangan orang kaya. Kelas sosial rendah hanya beberapa kali diceritakan melalui karakter pasien saja. Berdasarkan pada hasil dan pembahasan terhadap Webtoon Sekotengs karya Lifina maka diperoleh kesimpulan bahwa pandangan dunia yang disajikan dalam cerita tersebut adalah materialisme dan idelaisme. Pandangan dunia yang dominan adalah materialisme. Melalui karyanya, Lifina beranggapan bahwa sesuatu yang baik secara fisik atau secara material akan lebih mudah diterima oleh masyarakat. Ketampanan atau kecantikan selalu menjadi pokok permasalahan dalam Webtoon Sekotengs. Seseorang yang memiliki paras tampan atau cantik, pasti lebih diistimewakan daripada yang kurang tampan atau kurang cantik. Lifina juga berpandangan bahwa seseorang yang selain ketampanan atau kecantikan, kelas sosial yang tinggi juga menjadi tolok ukur dalam menilai seseorang sehingga dianggap sempurna serta diidolakan.

\section{Persantunan}

Terima kasih yang sebesar-besarnya penulis ucapkan kepada rekan-rekan dosen dan juga mahasiswa yang terus menyemangati dan mendorong penulis supaya dapat menyelesaikan tulisan ini dengan semaksimal mungkin. Berkat semangat tersebut alhamdulillah tulisan ini dapat diselesaikan. Terima kasih untuk Lembaga Penelitian dan Pengbdian Universitas Ahmad Dahlan karena atelah memberi fasilitas sehingga dosen dapat melaksanakan penelitian. Selaiin itu terima kasih kepada reviewer penelitian yang selalu memberi masukan agar kajian ini dapat lebih baik lagi.

\section{Daftar Pustaka}

Center, Charles B. Wang. "Webtoon: The Evolution of Korean Digital Comics”. diakses melalui https://www.artsy.net/show/charles-b-wangcenter-Webtoon-the-evolution-of-Koreandigitalcomics.

Dewi, Kartini Kusuma. 2019. Methodology Of Interpretation With Structuralism Approach In Adam Prophet'S Story. Journal of Islam and Science Vol.6 No I. hlm. I--7. diakses melalui laman http://journal.uinalauddin.ac.id/index.php/jis/article/view/8I5 $4 / 8233$

Faruk. 1994. Pengantar Sosiologi Sastra. Yogyakarta: Pustaka Pelajar.

Iskandar. 2012. "Dakwah dan Indovidualisme, Materialisme dan Hedonisme”. Jurnal Dakwah 
Tabligh Vol. I3 No. I. Hlm. I7--30 diakses melalui laman http://journal.uinalauddin.ac.id/index.php/tabligh/article/view $/ 292$

Jang Wonho dan Jung Eun Song. "Webtoon As A New Korean Wave in The Process of Glocalitation”. Journal Kritika Kultura. Vol. 29 hlm. I68--I87 diakses melalui laman https://barnettcenter.osu.edu/sites/default/fil es/2019.

08/webtoon_as_a_new_korean_wave.pdf

Jatnik, Asep Wawan., Ferry Fauzi Hermawan. 2018. "Menjadi Lelaki Sejati : Maskulinitas Dalam Komik Daring Webtoon Indonesia”. MUDRA Jurnal Seni Budaya Volume 33, No. I hlm: 60-66 diakses melalui laman https://jurnal.isidps.ac.id/index.php/mudra/article/view/I58

Lifina. 2018. Sekotengs. Diakses melalui laman https://www.webtoons.com/en/

Mawardi, Arif Budi. 2018. "Komodifikasi Sastra Cyber Wattpad Pada Penerbit Indie”. Sabda. Volume I3, Nomor I diakses melalui https://ejournal.undip.ac.id/index.php/sabda/ article/view/206I3/I3988.

Maharsi, Indria. 20II. Komik: Dunia Kreatif TanpaBatas. Yogyakarta: Kata Buku.

Nazemian, Houman. 2019. "Dystopia in Khalid Tawfik Utopia”. PEOPLE: International Journal of Social Sciences ISSN 2454 Volume 5 No $3 \mathrm{hlm} \quad$ 25I--26I https://grdspublishing.org/index.php/people/ article/view/2199/3648

Nnyagu, Uche Emma Nwafor. 2014. "Fiction as a Bland of Fact and Imagination in Chimamanda Ngozi Adichie's Purple Hibiscus”. International Journal of Arts and Humanties Bahir-Dhar Ethiophia Vol.3 (4) No. I2. hlm. I8--33 diakses melalui https://www.ajol.info/index.php/ijah/article/ view/II023I
Nurhasanah, Dewi. 2015 "Strukturalisme Genetik Lucian Goldmann dalam Novel Orang-orang Proyek Karya Ahmad Tohari”. Humaniora: Language, People, Art and Communication Studies Volume 6 No. I diakses melalui https://journal.binus.ac.id/index.php/Humani ora/article/view/3308/2692.

Safitri, Gita., Nurul Fitriani dan Ninda Wahyuni. 2019. "Pulau Bali dalam Pandangan Dunia Penyair Indonesia'. SATWIKA: Jurnal Kajian Budaya dan Perubahan Sosial Vol 3 No I hlm I3--26. diakses melalui laman http://ejournal.umm.ac.id/index.php/JICC/ar ticle/view/8679/6619.

Setiawati Devi, La Ino dan Mustika. 2019. "Pandangan Dunia Pengarang Dalam Novel Azizah Karya Emmah Azra”. Cakrawala Listra: Jurnal Bahasa Sastra dan Budaya Vol 2 No $2 \mathrm{hlm}$ I--20 diakses melalui laman http://journal.fib.uho.ac.id/index.php/cakrawa lalistra/article/view/778/609

Sirefina, Tisa, Khairil Anwar dan Hasanuddin. 2018. "Pandangan Dunia Pengarang dalam Novel Warisan Karya Chairul Harun:Tinjauan Strukturalisme Genetik". Jurnal Elektronik WACANA ETNIK Vol 7 No I hlm 36 - 57. http://jurnal.unswagati.ac.id/index.php/Deiksi s/article/view/I908/I I87

Sutopo. 2002. Metodologi Penelitian Kualitatif. Surakarta: Sebelas Maret University Press.

Wijianto, Agung. 2020. "Comparative Literature Study Of Motif Differences In Ragnarok And The Book Of Revelation” LIRE Journal (Journal of Linguistics and Literature) Vol. 4 No.I hlm 50--62 diakses melalui laman http://lirejournal.ubb.ac.id/index.php/LRJ/ar ticle/view/6I. 